\title{
POLYMERASE CHAIN REACTION IDENTIFYING PNEUMOCOCCAL COMMUNITY ACQUIRED PNEUMONIA IN CHILDHOOD
}

\section{BACKGROUND AND AIMS}

Streptococcus pneumoniae is the most common cause of communityacquired pneumonia (CAP), despite being underestimated due to low sensitivity of cultures. The utilization of molecular methods, like the polymerase chain reaction (PCR) can increase the identification of the etiologic diagnosis of CAP.

\section{METHODS}

This was a retrospective study, conduced in "Irmandade da Santa Casa de Misericórdia de São Paulo"/Brazil, from January/2012 to December/2017. We have included patients admitted due to severe CAP that was tested by lytA targeted PCR for Streptococcus pneumoniae detection. Chest X-rays were analyzed by radiologists, blindly.

\section{RESULTS}

Between January 2012 and December 2017, we have included 97 patients with CAP. The median age was three years (IQR=1-6 years), the median length of stay 13 days (IQR=7-22 days) and $3(3.2 \%)$ deaths. There were $24.2 \% \quad(n=23)$ patients that had used antibiotics previous to admission. Pleural effusion occurred in $46.4 \%(n=45)$ of the children, and it was associated with positive serum PCR ( $p=0.002)$. Pneumococcus was detected in $12.5 \%(n=11)$ of the cases by PCR, all of them with pleural effusion. There were six positive blood cultures, 2 of them with $S$. pneumoniae identified, 3 with Haemophilus $\mathrm{sp}$ and 1 with $S$. aureus. Of the patients with positive blood culture, two of them had positive PCR: one with S.pneumoniae in the blood culture and the other with Haemophilus sp.

\section{CONCLUSIONS}

The use of PCR increased the diagnosis in patients with culturenegative community-acquired pneumonia. The method seemed to be more sensitive in those with most severe pneumonia.

TABLE: Streptococcus pneumoniae numeric distribuition and its frequencies in blood cultures, pleural effusion cultures and polymerase chain reaction (PCR) in sérum and pleural effusion, from January/2012 to December/2017 in children with community-acquired pneumonia

\begin{tabular}{|l|l|l|l|l|}
$\begin{array}{l}\text { Streptococcus } \\
\text { pneumoniae }\end{array}$ & Blood cultures $(\mathrm{N}=63)$ & $\begin{array}{l}\text { Pleural effuusion } \\
\text { Cultures }(\mathrm{N}=28)\end{array}$ & PCR in serum $(\mathrm{N}=89)$ & $\begin{array}{l}\text { PCR in pleural } \\
\text { effusion }(\mathrm{N}=23)\end{array}$ \\
\hline Positive & $\mathrm{n}=2(3,2 \%)$ & $\mathrm{n}=2(7,1 \%)$ & $\mathrm{n}=13(14,6 \%)$ & $\mathrm{n}=16(69,5 \%)$ \\
\hline Negative & $\mathrm{n}=61(96,8 \%)$ & $\mathrm{n}=26(92,9 \%)$ & $\mathrm{n}=76(85,4 \%)$ & $\mathrm{n}=7(30,5 \%)$ \\
\hline
\end{tabular}

